\title{
Some Aspects of the Cloud Formation and the Airmass Modification over the Japan Sea in Winter Revealed by TIROS Observation (Part II)
}

\author{
by \\ K. Ninomiya \\ Meteorological Research Institute, Tokyo \\ (Received October 11, 1966)
}

\begin{abstract}
The aspects of the cloud formation over the Japan Sea during the three day period from Feb. 10 to Feb. 12, 1962 was analysed by using T.V. data and channel 2 radiation data of TIROS IV in the author's previous report.

In this report, the distrribution of the albedo over the Japan Sea and her neighbourhood during the period mentioned above is obtained by using channel 3 radiation data. The bright areas in channel 3, which indicate solid overcast, are very well correlated to low equivalent black body temperatures in channel 2. The estimations of cloud cover and cloud height over the Japan Sea are tried by coordinating the albedo and equivalent black body temperature. It is shown that, under the winter monsoon situation, cloud cover increases rapidly $2-300 \mathrm{~km}$ off the shore of the Japan Islands and that the cloud exists mainly under the inversion layer.
\end{abstract}

\section{Introduction}

Several works have shown that the distribution of effective temperatures measured by infrared channels and also that of reflected solar radiation measured by solar channels have a close correlation with the cloud cover (HANEL and STROud 1961, Fritz and Winston 1962, NordBerg et al 1962, RasoAl 1964). It is well known that channel 2 , the so called atmospheric window channel $(8-12 \mu)$, gives us the equivalent black body temperature of the earths surface and/or dense cloud surface. Almost all the parts of the reflected solar radiation are covered by channel 3 radiometer $(0.2-6.0 \mu)$ of TIROS IV. Hence the albedo of cloud and/or the earth's surface is easily obtained.

In his previous paper (Part I, 1966), the author discussed the aspects of cloud formation over the Japan Sea under the typical winter weather situation during the three-day period from Feb. 10 to Feb. 12, 1962, by using T.V. data and channel 2 radiation data.

In this paper, the distribution of albedo over the Japan Sea and her neighbour- 
hood will be discussed in Section 2 for the period under consideration. Comparisons between the distribution of albedo, that of equivalent black body temperature (which is obtained in Part I) and the synoptic cloud data are next made in Section 3. Combining these values of albedo and black body temperature, the cloud cover and the height of cloud over the Japan Sea under the winter monsoon situation will be estimated in the last section.

\section{Estimation of albedo}

The chanel $3(0.2-6.0 \mu)$ radiation data of TIROS IV orbit 0021, 0035 and 0049 printed out in the listings of the Final Meteorological Radiation Tape (FMRT) are used as the basic data in this report.

It is necessary first to refer to TIROS IV Radiation Data Catalog and User's Manual (NASA 1964) about the degradation of the channel 3 radiometer. The pastlaunch degradation has been observed as the decrease in the value of the quasi-global albedo. The quasi-global albedo $A^{i}$ of channel 3 is obtained as a function of orbit number (Fig. 1) by NASA. The figure indicates that $A^{i}$ decreased rapidly during the

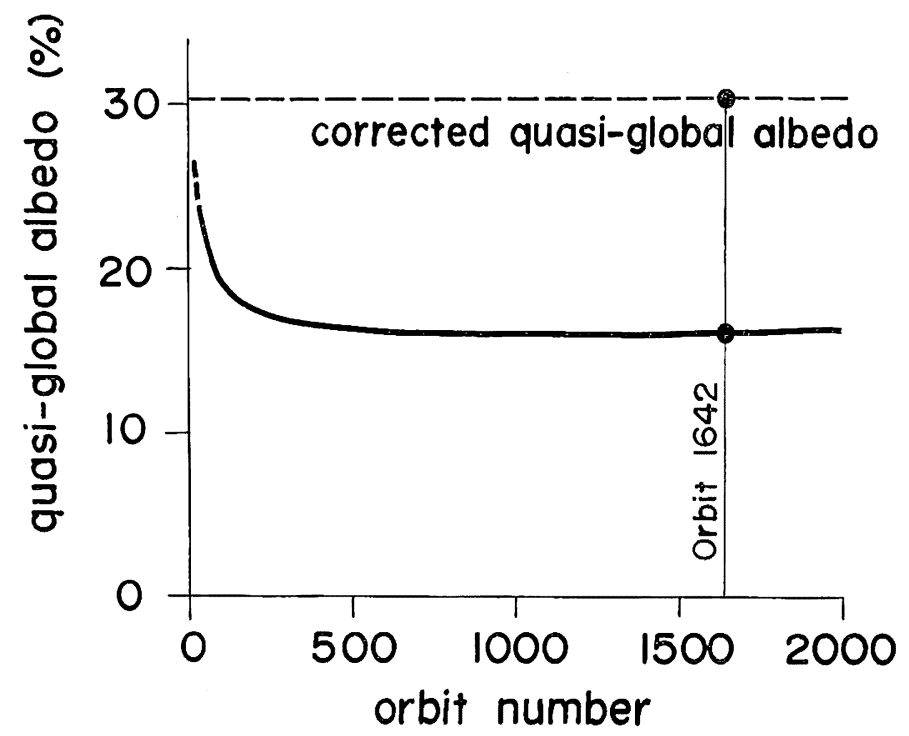

Fig. 1. The quasi-global albedo of channel 3 (solid line) and the corrected quasi-global albedo (broken line) (after Staff Members of NASA (1963)).

first week after the launch. After orbit 600, the curve levels off, indicating that the instrumental response has stabilized. The radiometer, similar to the one carried on TIROS IV, was flown on a balloon over South Dakota on 2 June 1962. Radiation data from the same area were obtained by the TIROS IV radiometer on orbit 1642 at $21^{\mathrm{h}} 43^{\mathrm{m}}$ GMT of the same day. The comparison indicates that the balloon measurement of channel 3 shows higher values than the satellite measurement by a factor of about 1.84. Thus the corrected channel 3 value of $A^{i}$ at orbit 1642 becomes 


$$
A_{\text {cor }}=1.84 \times 16.5=30.4 \%
$$

(Staff Members of NASA, 1963)

Also, the quasi-global albedo value of $30.7 \%$ is obtained by the quasi-global $\left(55^{\circ} \mathrm{N}\right.$ $55^{\circ} \mathrm{S}$ ) radiative energy budget (Staff Members of NASA, 1963). As the quasiglobal albedo is expected to be almost constant, the value of $\alpha$

$$
\alpha=30.5 / A^{i}
$$

is adopted as the correction factor for the reflected solar energy measured on each orbit.

In plotting the reflected solar energy given by the FMR' listing, the value obtained by the scan spot whose nadir angle exceeds $60^{\circ}$ is omitted. The distributions of reflected solar energy $Q_{r}$ thus obtained at 2358-0008 Z Feb. 9-10, 2321-2331 Z, Feb. 10 and 2244-2254 Z Feb. 11, 1962 are presented in Fig. 2 by solid lines.

Next the incoming solar energy per unit horizontal area at the top of the atmosphere, $Q_{0}$, is obtained for the time of the three orbit mentioned above. If $\zeta$ is the zenith distance of the sun, and the solar constant is assumed to be $1400 \mathrm{wat} \cdot \mathrm{m}^{-2}$ $\left(=21 \mathrm{y} \cdot \mathrm{min}^{-1}\right)$, then $Q_{0}$ is written as

$$
Q_{0}=1400 \cos \zeta .
$$

The zenith distance of the sun $\zeta$ is given as

$$
\cos \zeta=\sin \varphi \cdot \sin \varphi_{s}+\cos \varphi \cdot \cos \varphi_{s} \cdot \cos \left(\lambda-\lambda_{s}\right),
$$

where $(\varphi, \lambda)$ and $\left(\varphi_{s}, \lambda_{s}\right)$ are the latitude and longitude of the point on which $Q_{0}$ is to be obtained and these of the sub-solar point respectively. The isolines of $Q_{0}$ thus obtained are shown by thin broken lines in Fig. 2.

From the distribution of both reflected solar energy and the incoming solar energy, the albedo $a$, defined by

$$
a=Q_{r} / Q_{0}
$$

is obtained. The distributions of albedo at the same times as in Fig. 2 are presented in Fig. 3. The albedo varies from about $70 \%$, which is observed to the south of the Japan Islands at $2250 \mathrm{Z} \mathrm{Feb.} \mathrm{11,} \mathrm{to} \mathrm{a} \mathrm{few} \mathrm{percent,} \mathrm{which} \mathrm{is} \mathrm{found} \mathrm{over} \mathrm{the} \mathrm{northern}$ Japan Sea at $2250 \mathrm{Z}$ Feb. 11, 1962.

\section{Distribusion of albedo and equivaleut black body temperature in relation to the cloud systems}

The relations among the distribution of albedo, equivalent black body temperature of channel 2, which obtained in Part I of this paper, and the cloud system will be discussed in this section.

It is necessary to begin with the explanation of the synoptic weather situation during the analysed period in order to interpret the radiation data. The surface weather maps at 00Z, Feb. 10, 11 and 12, 1962 are presented in Fig. 4. (Also see, Figs. 2 and 

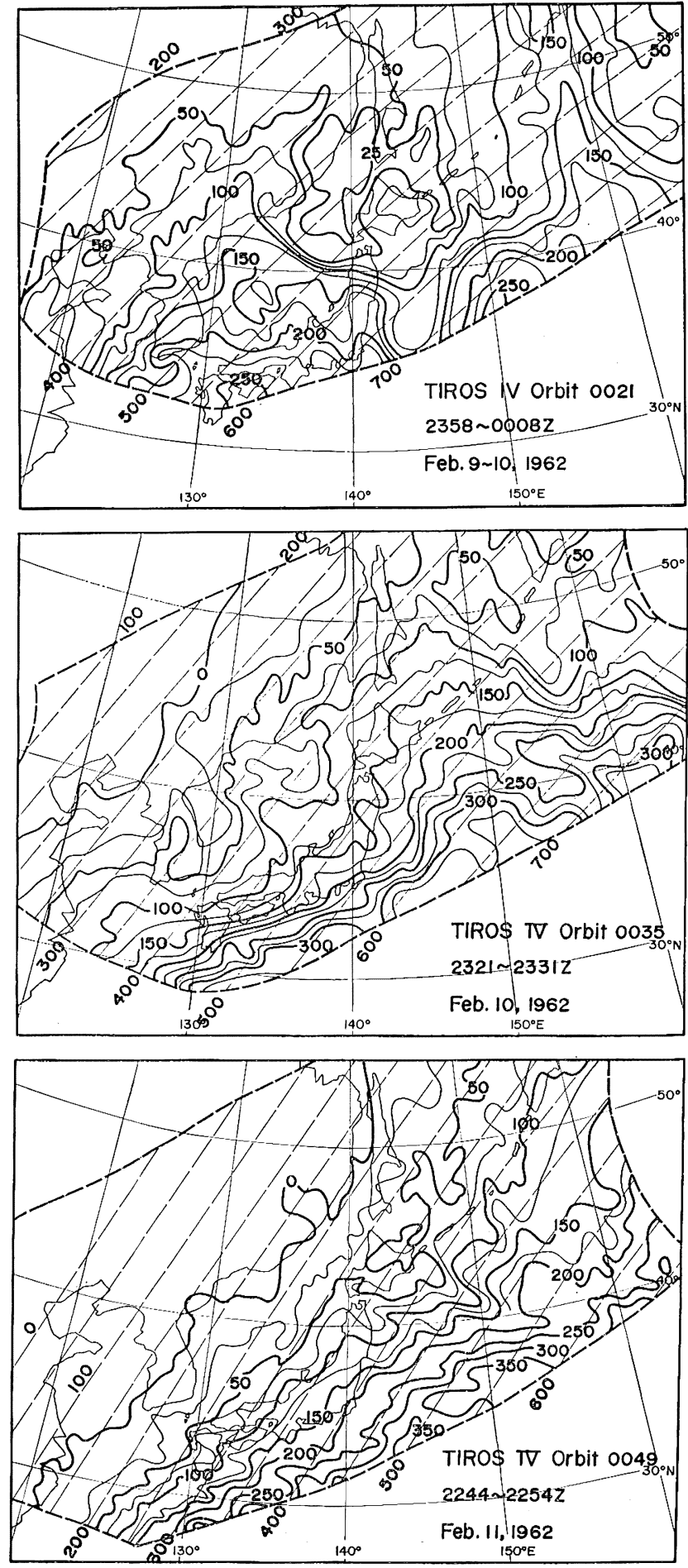

Fig. 2. The distribution of the reflected solar energy (solid line) and the incoming solar energy per unit horizontal area (thin broken line) at 2358-0008Z Feb. 9-10, 23212331Z Feb. 10 and 2244-2254Z Feb. 11, 1962. (unit is Watt $\cdot \mathrm{m}^{-2}$ ). 


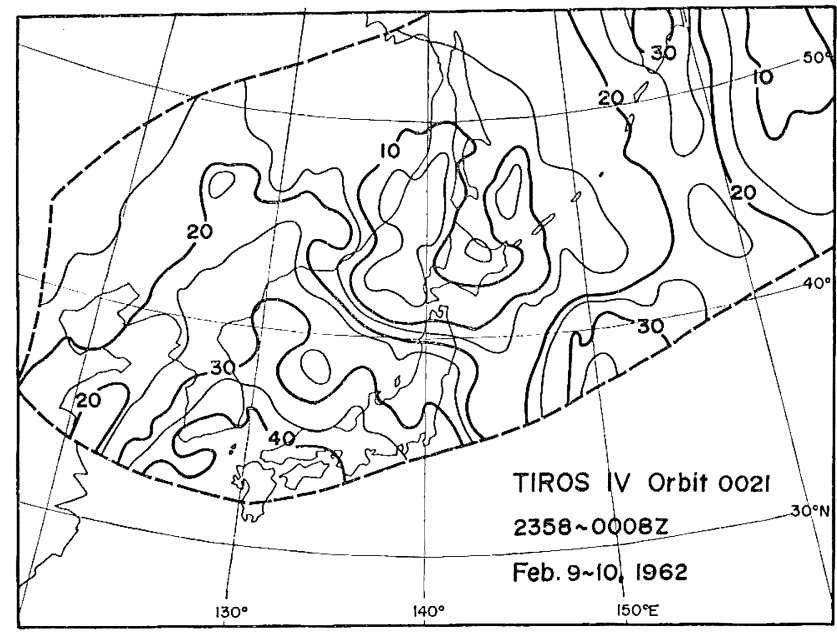

Fig. 3. The distribution of albedo at 2358-0008Z Feb. 9-10, 2321-2331Z Feb. 10 and 2244-2254Z Feb. 111962. (unit is \%)
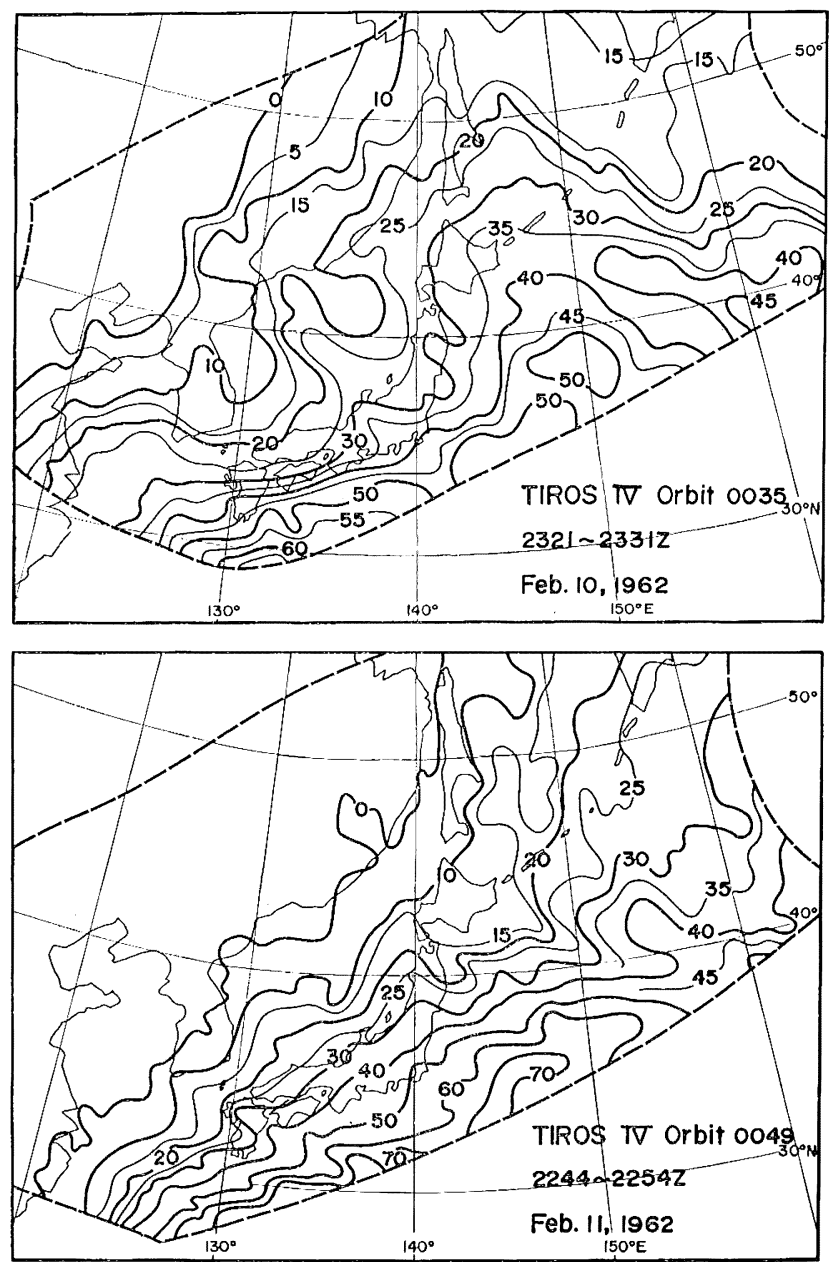

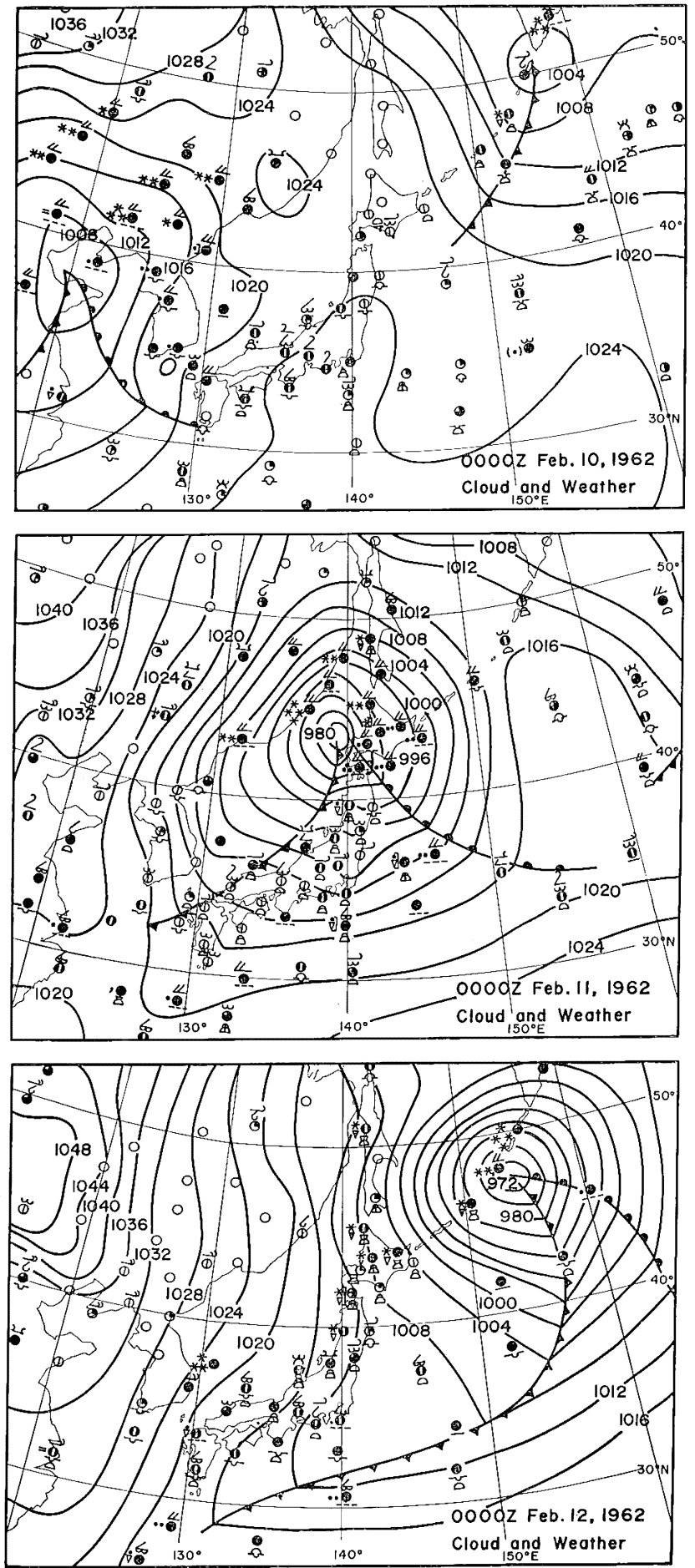

Fig. 4. The surface weather maps at $0000 Z$, Feb., 10, 11 and 12, 1962. 
3 of Part I, concerning the upper lever charts and the meridional cross sections).

At $0000 \mathrm{Z}$ Feb. 10, 1962, a cyclone which developed in front of the upper westerly trough is located to the west of the Korea Peninsula, and another occluded cyclone is located on the northwestern Pacific. Areas of solid overcast are observed over the northeastern China, the Korea Peninsula and the western part of the Japan Islands. Clear weather was found around the northeastern Japan Sea, where the ridge aloft was located.

At $0000 \mathrm{Z}$ Feb. 11, the cyclone, which developed rapidly during its passage over the Japan Sea, was located on the west coast of Hokkaido and a cold front was extending along the Japan Sea coast line. Solid overcast and snowy weather were found over Hokkaido, Saghalien and the northeastern Japan Sea.

At $0000 \mathrm{Z}$ Feb. 12, the cyclone moved farther east to the northwestern Pacific and a remarkable cold air outbreak was taking place. Areas of overcast are observed over the cyclone and the cold front to the south of the Japan Islands. The strong temperature gradient over the Japan Sea leads us to infer a remarkable modification of the air mass. The solid overcast and snow shower are observed actually over the Japan Sea coastal region, while the area of clear weather extends over the continent.
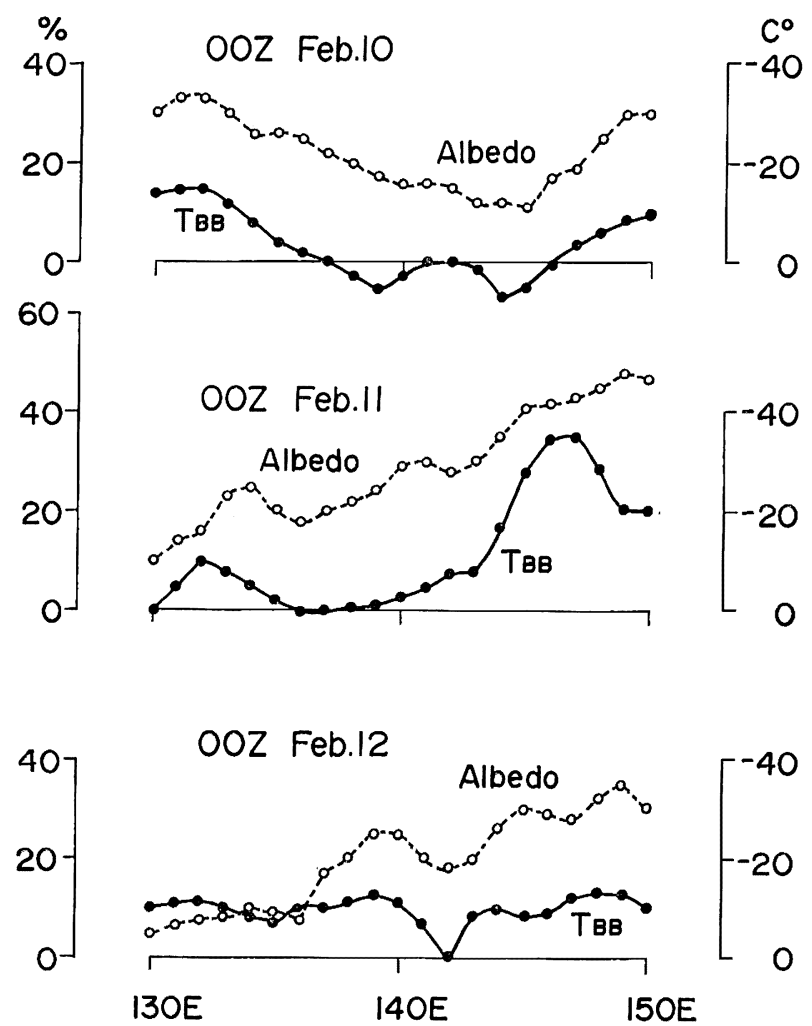

Fig. 5. The variations of albedo and the equivalent black body temperature along $40^{\circ} \mathrm{N}$ latitudinal circle. 
It is easily recognized by comparing the surface weather maps (Fig. 4) with the maps of albedo distribution (Fig. 3) that the bright area in channel 3 or, in other words, the area of high albedo indicates solid overcast.

For a comparison between the distribution of albedo and that of equivalent black body temperature which is obtained by using channel 2 observation (see Fig. 6 in Part I of this report), the distributions of these value along the $40^{\circ} \mathrm{N}$ latitudinal circle are presented in Fig. 5. As seen in the figure, the high albedo is very well correlated to low equivalent black body temperature and vice versa.

At $0000 \mathrm{Z}$ Feb. 10, 1962, areas of high albedo are found over $130^{\circ} \mathrm{E}$ and $150^{\circ} \mathrm{E}$, where the low $\mathrm{T}_{\mathrm{BB}}$ (equivalent black body temperature is written as $\mathrm{T}_{\mathrm{BB}}$ hereafter for convenience) is also observed. The former corresponds to the cloudy area in front of the cyclone to the east of the Korea Peninsula and the latter to the cloudy zone over the cold front extending from an occluded cyclone over the Kamchatka Peninsula. An area of notable high albedo and low $\mathrm{T}_{\mathrm{BB}}$ is found over $145^{\circ} \mathrm{E}$ in front of the rapidly developing cyclone at 0000Z Feb. 11.

The figure for $0000 \mathrm{Z}$ Feb. 12 shows the cloud distribution in the polar air mass which breaks out from the continent as the winter monsoon. As the air mass flows over the relatively warm Japan Sea, the cloud amount increases and the maximum of albedo and the minimum of $\mathrm{T}_{\mathrm{BB}}$ is found over the Japan Sea coastal area $\left(139^{\circ} \mathrm{E}\right)$. The low albedo and high $\mathrm{T}_{\mathrm{BB}}$ over $141-142^{\circ} \mathrm{E}$ indicates the clear weather which appears usually over the lee side of the Japan Islands under a winter monsoon situation. The albedo increases again as the air mass flows over the warm Pacific.

The $\mathrm{T}_{\mathrm{BB}}$ in the regions of overcast cloudiness is to be related to the temperature, and hence to the height, of the cloud top. As isotherms are drawn on each standard pressure map, the contours of cloud top height are easily obtained (see Fig. 7 of Part I). To see the relation between the height of the cloud top and its albedo, the distributions of both height and albedo are shown in the composite maps (Fig. 6).

The region of overcast cloudiness in front of the cyclone at an early stage of its development is characterized with a high cloud top (about $500 \mathrm{mb}$ ) and fairly high albedo (20-30\%). The observation station in the region mentioned above reports a thick altostratus or nimbostratus. The albedo increases to $30-50 \%$ as the cyclone gets at the occluded stage (23Z Feb. 10).

When the cold front is analysed over the Japan Sea (2300 Z Feb. 10) by using the synoptic weather report, no evidence of its existence is given by the albedo or $\mathrm{T}_{\mathrm{BB}}$. On the contrary, when the cold front moved over the Pacific (2300 Z Feb. 11), a very low $\mathrm{T}_{\mathrm{BB}}$ (the top of cloud is estimated to reach $400 \mathrm{mb}$ ) and a very high albedo of $60-70 \%$ are reported. The vertical crass section along $140^{\circ} \mathrm{E}$ meridian shows that a deep moist layer exceeding $400 \mathrm{mb}$ exists over the cold front (see Fig. 3 of Part I). It could be said that both mixing ratio of water vapour and air temperature were too low over the Japan Sea for convective clouds associated with the cold front to develop sufficiently.

The existence of convective cloud is reported by each observation station along the Japan Sea coastal area under the situation of cold air outbreak (2300 Z Feb. 11). 


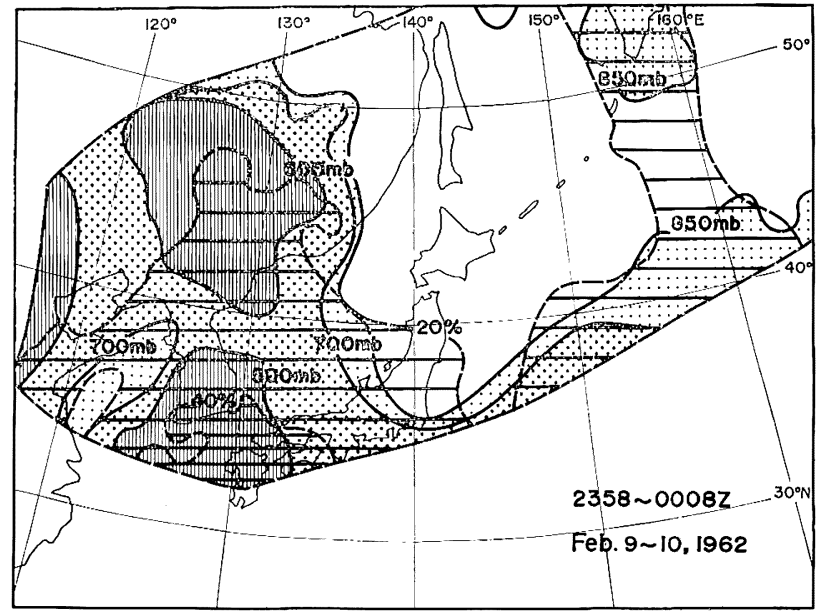

Fig. 6. The composite maps to show the relation between the albedo and the height of the cloud top which is estimated from $\mathrm{T}_{\mathrm{BB}}$.
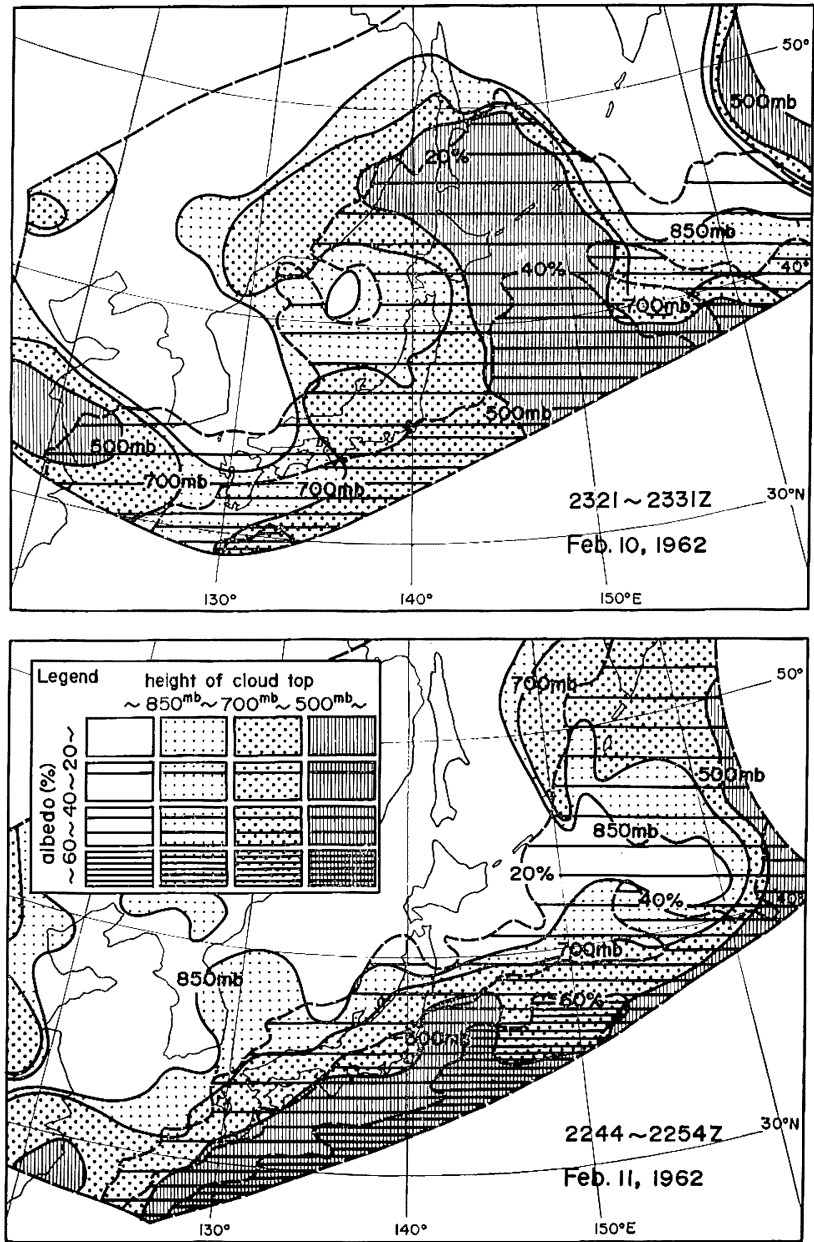
Although fairly high albedo (30\%) is found over the area above mentioned, the rather high $\mathrm{T}_{\mathrm{BB}}$ indicates that the elevation of the cloud top is not so high. The detailed discussions about cumulus formation and its relation to the inversion layer in the polar airmass will be made in the next section.

\section{Some aspects of cloud formation over the Japan Sea under the situation of a winter monsoon.}

The height of the cloud top over the Japan Sea was estimated very roughly in Part 1 of this report, by using the value of $T_{\mathrm{BB}}$ only. Here, more reasonable estimation is to be tried by coordinating the values of both albedo and $\mathrm{T}_{\mathrm{BE}}$.

As mentioned in Section 3, the vulues of $\mathrm{T}_{\mathrm{BB}}$ in the regions of overcast cloudiness are to be related to the temperatures, and hence to the height of the cloud top. In regions of broken and/or scattered clouds, the situation is more complex, because both cloudiness and height are unknown parameters. The values of $T_{B B}$ and the corresponding cloud top height in this case are more difficult to interpret.

The T.V. cloud photograph, Frame 31 of orbit 0038, taken at 0445Z Feb. 11, 1962 and the map showing the distribution of albedo and $\mathrm{T}_{\mathrm{BB}}$ for $2326 \mathrm{Z} \mathrm{Feb.} 10$ (orbit 0035) drawn in the same scale as Frame 31 are presented in Fig. 7. It is noticeable that the area of low albedo is observed just over the clear area near the continent. This fact means the possibility of relating albedo to the cloudiness. The cloudiness can be measured, of course, if the T.V. cloud photograph is available. The T.V. observation, however, is not always made simulateneously with radiation observations, and thus, it is necessary to estimate both cloudiness and cloud height by using radiation data only.


Fig. 7. T.V. cloud photograph Frame 31, orbit 0038 taken at $0445 \mathrm{Z} \mathrm{Feb.} \mathrm{11,} 1962$ and the distribution of albedo (solid line) and TBB (broken line) for $2326 \mathrm{Z} \mathrm{Feb.} \mathrm{10,} \mathrm{drawn}$ in the same scale as in Frame 31. 
It should be noted that the scan spot on the earth viewed by the radiometer of TIROS IV has a diameter of about $70 \mathrm{~km}$. In other words, the value of albedo and $\mathrm{T}_{\mathrm{BB}}$ mentioned above are the mean values over a radiometer scan spot whose diameter is about $70 \mathrm{~km}$. Thus the following relations on the albedo and $T_{\mathrm{BB}}$ are expected;

$$
\begin{aligned}
& a=n a_{c}+(1-n) a_{s} \\
& \mathrm{~T}^{4} \mathrm{BB}=n T_{c}{ }^{4}+(1-n) T_{s}{ }^{4}
\end{aligned}
$$

where, $a$ and $\mathrm{T}_{\mathrm{BB}}$ are the albedo and equivalent black body temperature obtained by radiometer over a scan spot, $n, a_{c}, a_{s}, T_{c}$ and $T_{s}$ are the cloudiness, albedoes of the cloud and sea surface, temperatures of cloud top and sea surface respectively.

The distribution of $a$ and $T_{\mathrm{BB}}$ along the airmass trajectory over the Japan Sea under the winter monsoon are shown in Fig. 8. Also the evaporation and sensible heat supply from the sea surface estimated by Jacobs' formula are presented in the figure.

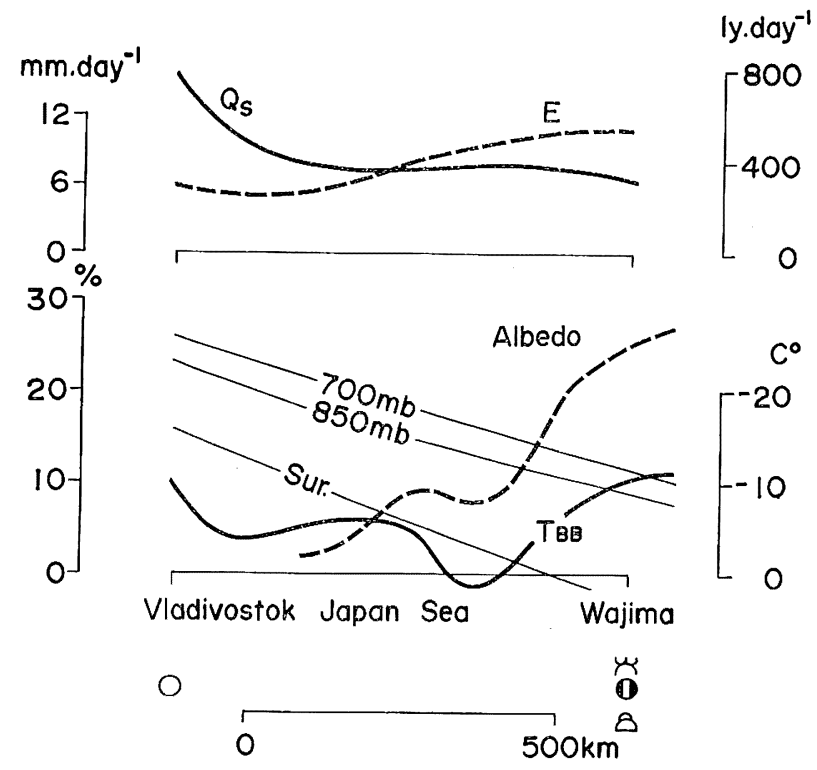

Fig. 8. The variations of heat $\left(Q_{s}\right)$ and moisture (E) supply from the sea surface obtained by Jacobs' formula along the airmass trajectory over the Japan Sea (upper figure). The variations of albedo TBB and temperature at standard pressure levels along the airmass trajectry (lower figure).

It is assumed that the value of $a_{c}$ (i.e. albedo of cloud) is constant, as the situation of cloud would be rather uniform over the Japan Sea, at least over its coastal area. Just over the coastal area of the Hokuriku district, where synoptic stations report cumulus and/or strato cumulus overcast. (i.e. $n=1.0$ ), the observed value of $a$ is 0.30 . Therefore the value of $a_{c}$ is considered as 0.30 . This value should not be considered as the albedo of cumulus itself. It is known by aerial photographic ob- 
servation that the cumulus top is rather flat and also stratified cloud like stratocumuls coexists with cumulus under the inversion layer when the winter mosoon predominates (MAtsumoto and NinomiYA, $1966 a$ and $1966 b$ ). Thus the albedo of 0.30 is to be understood as the mean albedo of cumulus and stratocumulus.

The albedo of developed cumulus would be larger and its cloudiness would be smaller, even an overcast situation is reported by the synoptic weather station. The albedo of the sea surface is decided to be 0.05 by a comparison between the T.V. cloud photograph and the albedo distribution (Fig. 7). Thus the cloudiness $n$ is obtained as

$$
n=\frac{a-a_{s}}{a_{c}-a_{s}}
$$

Then the temperature at the cloud top $T_{c}$ is written as

$$
T_{c}{ }^{4}=\frac{T_{\mathrm{BB}^{4}}-(1-n) T_{s}{ }^{4}}{n}
$$

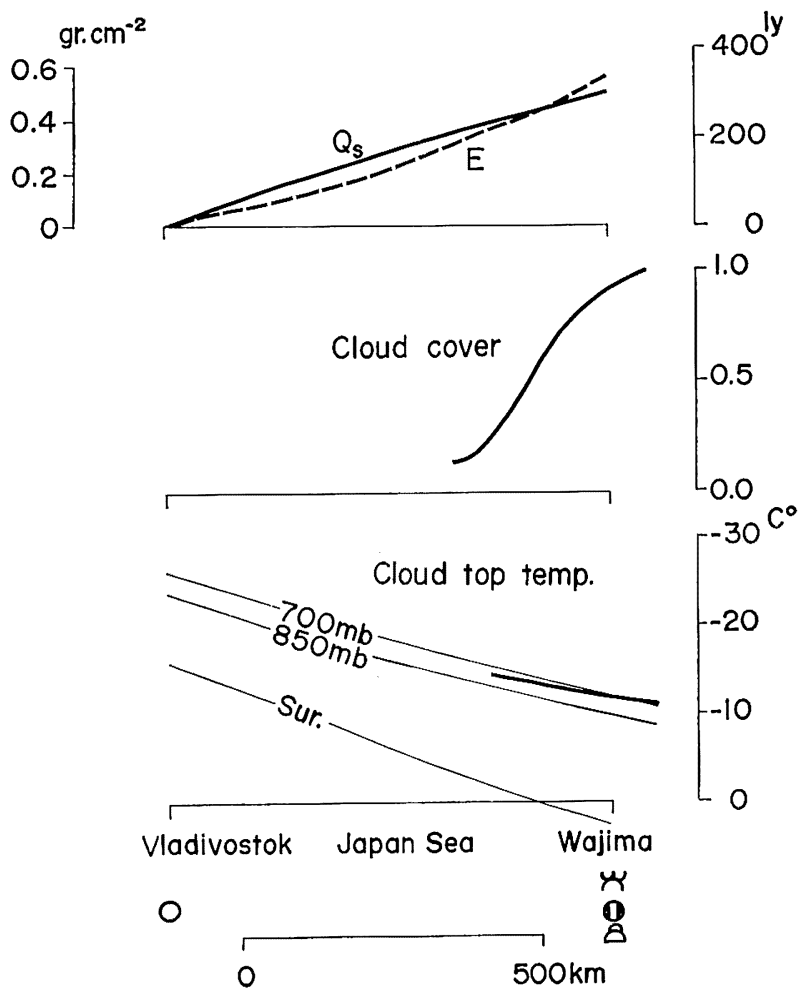

Fig. 9. The upper figure : the cumulative amount of sensible heat and water vapor which are gained in the air column after the airmass goes away from the continent. The lower figures; The variations of cloudiness and the height of the cloud top along the airmass trajectory. 
The estimated distributions of $n$ and $T_{c}$ are presented in Fig. 9. The cloudiness begins to increase remarkably about $200-250 \mathrm{~km}$ off the shore of the Japan Sea coastal line, while the temperature of the cloud top is rather uniform, i.e. $-15^{\circ}--12^{\circ} \mathrm{C}$. The height of the cloud top is estimated by comparing $T_{c}$ with the temperature on each standard pressure level. The result is that the height of cloud top is $850 \mathrm{mb}$ about $250 \mathrm{~km}$ off the shore and increases only gradually to $800-750 \mathrm{mb}$.

The soundings at Wajima and Akita for $0000 \mathrm{Z}$ Feb. 12, 1962 are presented in Fig. 10. It is notable that a well developed inversion layer exists in the lower troposphere and that humidity rapidly decreases above the lower boundary of the inversion, and almost saturated moist air is only observed in the sub inversion layer. Thus it would be concluded that the estimated cloud height by using TIROS radiation data corresponds with the humidity sounding. Similar situations are also analysed by Matsumoto and Ninomiya (1966 $a$ and $1966 b$ ) by using the aerial photographic observation of cloud and also the drop sonde observation" over the Japan Sea.

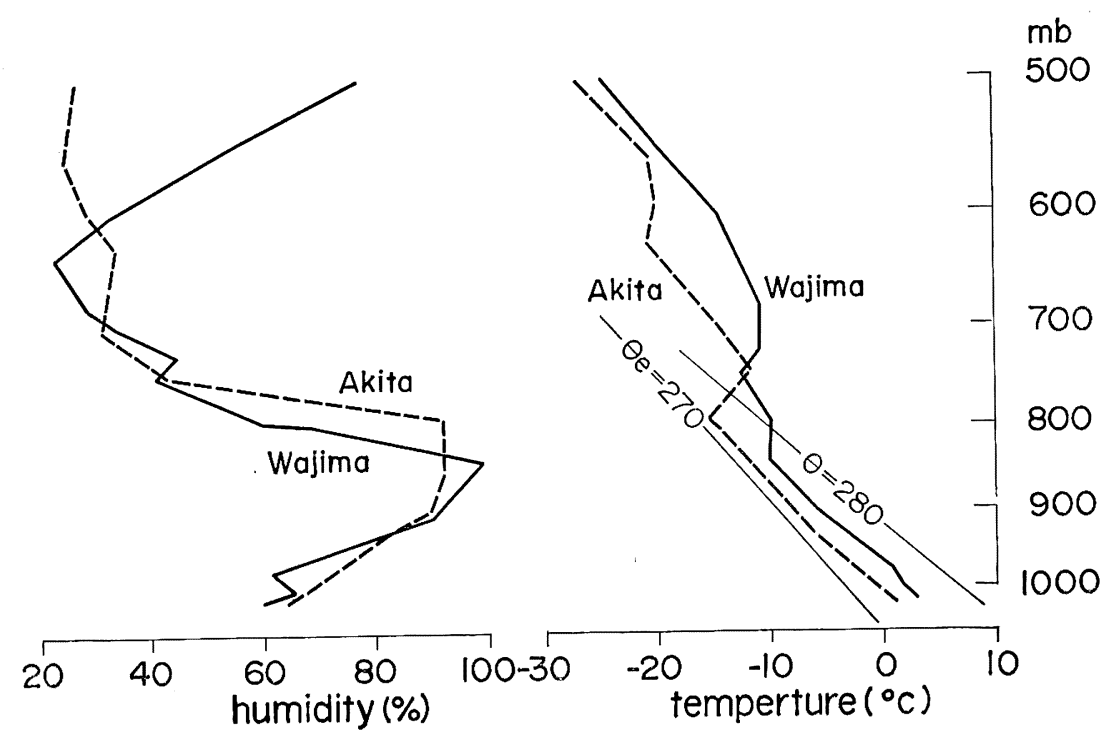

Fig. 10. The sounding of temperature and humidity at Wajima (solid line) and Akita (broken lind), for $0000 \mathrm{Z} \mathrm{Feb.} \mathrm{12,} 1962$.

As cumulus formation is highly correlated with the modification of the airmass, it is necessary to compare the increase of cloudiness mentioned above with the sensible heat and water vapor supplied to the airmass. The accumulative amounts of the sensible heat and the water vapor which are gained in a unit air column after the airmass goes away from the Continent, calculated along the airmass trajectory, are shown in Fig. 9. The result shows that the cloud formation is remarkably intensified when or after the air column gets $200 \mathrm{ly}$ of sensible heat and $0.4 \mathrm{gr} \cdot \mathrm{cm}^{-2}$ of water vapor during its passage over the Japan Sea surface. It can also be said that the early supply of $0.4 \mathrm{gr} \cdot \mathrm{cm}^{-2}$ of water vapor works mostly to moisten the dry airmass and a considerable part of the additional supply thereafter is consumed to generate cloud or as the precipitation. 


\section{Conclusion}

The results of Part II of the present report, the analysis of cloud formation over the Japan Sea in winter by using TIROS IV channel 3 radiation data, are summarized as follows:

1. The areas of high albedo, which indicate solid overcast are very well correlated to low equivalent black body temperatures obtained by channel 2 rediation measurment.

2. The albedo of $30 \%$ is observed on the cumulus overcast over the down stream side of the Japan Sea under the winter monsoon situation. The albedo of sea surface is known to be $5 \%$.

3. The cloudiness is estimatted by using the albedo distribution, then the cloud height is estimatted in both overcast and broken area by using channel 2 radiation data. The results of this estimation coincide with the data of synoptic cloud observation.

4. The cloudiness increases rapidly after the airmass gets $0.4 \mathrm{gr} \cdot \mathrm{cm}^{-2}$ of water vapor during its passage over the Japan Sea.

5. The height of the cloud top is rather uniform, about $800 \mathrm{mb}$ over the coastal area. This height coincides with the height of inversion base.

Acknowledgment-The author expresses his hearty tanks to Dr. K. TAKAHASH and Dr. S. Matsumoto for stimulations and helpful suggestion.

\section{References}

FRITZ, S. and J. S. Winstons, 1962: Synoptic use of radiation measurements from stellite TIROS II. Mon. Wea. Rev., 90, 1-9.

HANEL, R. A. and W. G. Stroud, 1961: The TIROS II radiation experiment. Tellus 13, 486-488.

Matsumoro, S. and K. NinomiYa, 1966 a: Some aspects of the cloud formation and its relation to the heat and moisture supply from the Japan Sea surface under a weak monsoon situation. Journ. Met. Soc. Japan. 44, 60-75.

Matsumoto, S. and K. Ninomiya, $1966 \mathrm{~b}$ : Some aspects of the inversion layer over the Japan Sea under a winter monsoon situation as revealed by drop-sonde and aerial photographic observation. Pap. in Meteor. and Geophys. 17, 51-64.

Ninomiya, K., 1966: Some aspects of the cloud formation and the airmass modification over the Japan Sea in winter revealed by TIROS observation. Pap. in Meteor. and Geophys., $16,157-178$.

Nordberf W., W.R. Bandeen B. J. Conrath, V. Kunde and I. Persano, 1962: Preliminary results of radiation measurement from TIROS III Meteorological satellite. J. Atmos. Sci. 19, 20-29.

Rasoor, S. I., 1964: Cloud heights and nighttime cloud cover from TIROS radiation data. J. Atmos. Sci. 21, 152-156.

Staff Members of the Aeronomy and Meteorology Division, Goddard Space Flight Center,

NASA., 1963: TIROS IV Radiation Data Catalog and User's Manual. Aeronomy and Meteorology Division Goddard Space Flight Center, NASA. pp. 250. 


\title{
TIROS 資料による冬期日本海上における雲の発生と 気団変質の解析（第 2 報）
}

\author{
二 宮 洸 三
}

1962年 2 月 10 日朝鮮半鳥西岸飞位置した低気压は，11日発達しつつ日本海上を通過し，〉きつづき12日

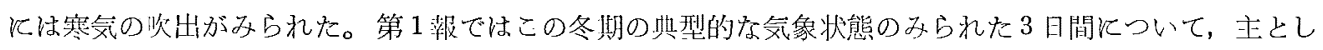
て TIROS IV の channel 2 輻射資料をむちいて日本海上での雲の分相・発生状況を調べたが，この報告 ではさらK channel $3(0.2-6.0 \mu)$ 輻射資料をあちいて albedo の分布を求め, 前報の絬果之あわせて,

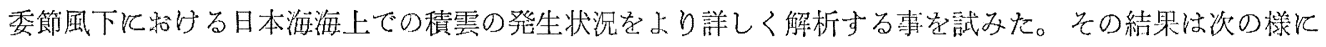
要約される。

1. albedo, channel 2 equivalent black body temperature (ТВB) 拉よび雲量分布の間飞は非常飞 高い相関が見出された。

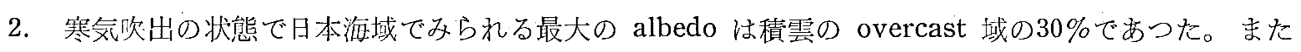
$\mathrm{T} . \mathrm{V}$ 写真との比較によつて海面の albedo は $5 \%$ である事が知られた。

3. albedo 分布から雲量を推定し, ついで T及B から雲頂高度の推定を行なつた。この推定は雲量10以 下の部分飞特いても行なわれ得るが，その結果は他の钼测事歨とあよく一致した。

4. 雲量法日本海沿岸冲 $250 \mathrm{~km}$ 附近から急速飞增加しはじめる。気団の変質と比較すると気団が大陸 をはなれてからのち, 海面から $0.4 \mathrm{gr} ・ \mathrm{~cm}^{-2}$ 程度の水蒸気補給を受けた前後から雲量が急憎加してい る。

5. 雲頂高度の增加はゆるやかで, 250 300km 冲あいで $850 \mathrm{mb}$. 程度, 沿岸部分で $800 \sim 750 \mathrm{mb}$ 程度 である。この高さは, この日, 寒気団内部に存在した影著な逆転尿下面の高さと一致していた。

この卸告は気象研究所・北陸豪雪特別研究の一部分としてなされたすのである。 